\title{
The Right of Access to Health Care Services: Pitfalls and Prospects
}

\author{
Lufuno Nevondwe \\ Kola O. Odeku \\ Faculty of Management and Law, School of Law, \\ University of Limpopo, South Africa \\ E-mail: lufuno3@gmail.com
}

Doi:10.5901/mjss.2013.v4n13p837

\begin{abstract}
It is generally accepted that there is an equal access of right to health care facilities and deliveries. The apparent constitutional provisions and other related legislations expressly provide that everyone should have adequate and unrestricted access to health care services in South Africa. This article examines the extent to which everyone, under the current dispensation is accessing healthcare. The article points out the pitfalls inherent in health care services and at the same time highlights the milestones that have been achieved through legislative and practical interventions.
\end{abstract}

Keywords: Health care services, Deprivation, Progress, Challenges, Strategic policies interventions

\section{Introduction}

This article examines the appropriateness and effectiveness of the South African government policies and the right to have access to health care services. Health care availability is the primary source of inequality in contemporary society and in this regard South Africa is not different (Roston, 2005). During the draconian apartheid regimes, health services and delivery in South Africa were based on deliberate racial segregation policies and laws that removed the previously disadvantaged black persons from access to adequate health facilities. This unequal access to health care was used as an integral part of the apartheid regime to maintain White supremacy (Price, 1986). Even, in the current democratic dispensation, the problem is still inherent because, approximately forty percent(40\%)of South African youths and adults remain unemployed; they do not have either adequate housing or access to pipe water dwelling, and close to fifty percent(50\%) lack access to hygienic toilet facilities (Price, 1986).

These and other factors make South Africa to still remain as one of the most unequal societies in the world, and nowhere is this more apparent than in the two-tier health system made up of an under-funded public sector serving the needs of the poorer sixty eight percent (68\%) of the population, and a resource guzzling private sector serving the rest (Bachenberg et al. 2011). The private sector, operating in a weak regulatory context, is inclined towards excessive cost inflation while locked into a system offering declining benefits, in which the consumer has come to bear an increasing portion of the financial burden (Ncayiyana, 2008).

Andrews (2000) described the unequal access to health facilities thus "Health services in South Africa were divided according to race, geographic location and whether they were public or private services. The best services were provided in big cities to white people, who could afford medical aids and could go to private doctors and hospitals." As most black people could not afford private health care services, they had to make use of racist and inaccessible public health services (Andrews, 2000). Apartheid laws offered very little help to poor, black South Africans when they were ill (Aliber, 2003). The health system also failed to adequately address the health problems of the majority poor. Most of the money, doctors and equipments were used to address the complicated and expensive health needs of white patients, for example open heart transplant (De Vos, 2009).

The public sector depends on budget allocations determined largely in the context of the budget process rather than any explicit policy or plan. The allocations do not take into account such factors as population changes (including immigration) and changes in morbidity patterns (de Vos et al. 2007). Consequently, an over resourced private sector is coexisting alongside a public sector characterised by declining health budgets. In real terms, a growing burden of disease due to the HIVIAIDS pandemic, worsening health status indicators, the resurgence of communicable diseases and human resource shortfalls (Kahn, 2006). 
Health care services are often expensive and most people do not have access to private medical aid to pay for expensive treatment. There is a general shortage of doctors and nurses. This could be as a result of some doctors and nurses leaving the country for better salaries overseas. Due to this fact, many of the available doctors and nurses are overworked. (Price, 1998).

The democratic Constitution of South Africa has outlawed any form of racial discrimination and guarantees the principles of socio-economic rights including the right to health care. It is against the background of this that this paper seeks to explore the pitfalls and prospects facing the protection of human rights to health services in a predominantly poor and unequal society. Attempts to deal with these disparities and to integrate the fragmented services that resulted from fourteen health departments (serving the four race groups, including the Bantustans) did not fully address the inequities (van Rensburg and Benatar, 1993).

In South Afrca, there are two-tiered health systems, public and private, based on socio-economic status and it continues to perpetuate inequalities in the current health system (Migué, 2002). Attempts to reform the health care system have not gone far enough to extend coverage to bring about equity in health care. In many areas access to health care has increased in the public sector, but the quality of health care services has deteriorated and remains poor (Coovadia et al. 2009) According to the National Health Insurance(NHI) in South Africa, Policy Paper the public health sector will have to be significantly changed to shed the image of poor quality services that have been scientifically shown to be barrier to access of adequate and quality health services ( $\mathrm{NHI}$ )

\section{Objectives of the Study}

The objectives of the article are to examine how everyone in South Africa have been able to derive benefits from the constitutional promise of section 27 which provides that everyone has right to adequate health care. It also examines how to improve the quality of health services delivery in the public sector especially to the previously disadvantaged poor and the vulnerable.

\section{Literature Review}

The concept of health care services is not new in the South African legal system (Coovadia et al. 2009). Scholars have already researched on the right of access to health care services (Pieterse, 2007). According to Ngwena (2000), "the new South Africa is taking a holistic approach to respect health care as a basic human right." The Human Rights Commission has been monitoring the realisation of the right to health care services (Ngwena, 2000). The government's role is to encourage efficient use of resources and equally distribute resources to required positive constitutional duties to enforce the right to health care services (Sarkin, 1998).

Ngwena (2000) observed that "our courts are given jurisdiction to adjudicate over matters of policies, including budgetary appropriations. A right of access to health care means being able to access health care that is affordable, available and effective ( Campbell et al. 2000). As part of its social responsibility, government state must seek to deliver a package of essential health services according to universal standards within a scheduled period of time (Chopra et al. 2009).

Pieterse (2007) also sees health care as a basic human right issue. He states that "section 27 (1) (a) determines that 'everyone' is entitled to access health care services may be understood to indicate that rationing decisions may not be discriminatory and should adhere to the dictates of the right to equality. When read with the obligation of the state to "respect" the right in the Bill of Rights in section 7 (2) of the Constitution, section 27 (1) (a) may further be understood to require that rationing process and decisions respect existing access to health care services and may not have the effect of obstructing diminishing access (for instance, directing resources away from provision of services to which patients already have access (Pieterse, 2007).

According to Mubangizi (2007), he provides that health is a basic human right issue as well. He states that "the right to health is grounded on the fact that they guarantee everyone the right of access, not only to important components of adequate standard of living, but also to things that are ordinarily regarded as basic necessities of life."

It is submitted that South Africa has taken the bold step by recognising health as one of the necessities of life, and by constitutionally entrenching this right in the 1996 Constitution (Mabidi, 2013).

In the words of Mandela (1991)

"a simple vote, without food, shelter and health care is to use first generation rights as a smokescreen to obscure the deep underlying forces which dehumanize people. It is to create an appearance of equality and justice, while by 
implications of socio-economic, inequality is entrenched. We do not want freedom without bread, nor do we want bread without freedom. We must provide for all the fundamental rights and freedoms associated with a democratic society."

The term 'health services' is defined in section 1 of the National Health Act 61 of 2003 as-

(a) health care services, including reproductive health care and emergency medical treatment , contemplated in section 27 of the Constitution;

(b) basic nutrition and basic health care services contemplated in section 28 (1) (c) of the Constitution;

(c) medical treatment contemplated in section 35 (2) (e) of the Constitution; and

(d) municipal health services (Nienaber, 2009).

The Constitution contains a number of different references to health care services and medical treatments. South Africa is a society in which there are great disparities in wealth. Millions of people are living in deplorable conditions and in great poverty (Klasen, 1997). There is a high level of unemployment, inadequate social security, and many do not have access to clean water or adequate health services. These conditions already existed when the Constitution was adopted and a commitment was made to address them, and to transform our society into one in which there will be human dignity, freedom and equalityat the heart of our new constitutional order (Greenstein, 2006).

The constitutional commitment to address these conditions is expressed in the preamble of the Constitution which, after giving recognition to injustices of the past, states:

"We therefore, through our freely elected representatives, adopt this Constitution as the supreme law of the Republic so as to-Heal the divisions of the past and establish a society based on democratic values, social justice and fundamental human rights; Improve the quality of life of all citizens and free the potential of each person."

This commitment is also reflected in various provisions of the Bill of Rights For instance in section 7 where the Bill of Rights is described as the cornerstone of democracy in South Africa and as affirming "the democratic values of human dignity, equality and freedom."

In particular section 26 deals with the right to have access to adequate housing and section 27 of the Constitution deals with the right to have access to health care, food and social security.

\section{Research Methodology}

The methodology for this study is qualitative analytical approach. Consequently, a combination of legal comparative and legal historic methods, based on jurisprudential analysis, was used. Legal comparative method was applied to find solutions, especially in the interpretation of access to health care services. Concepts were analysed and arguments were developed around the issues of access to health care. A literature and case law survey of the constitutional prescriptions and interpretation of statute were examined and applied.

\section{Exploring Constitutional Promise of Section 27 of the Constitution}

Section 27(1)(2)(3) provide that "everyone has the right to have access to health care services, including reproductive health care, sufficient food and water, and social security. Appropriate social assistance is also provided for people if they are unable to support themselves and their dependants.. The state is obliged to take reasonable legislative and other measures, within its available resources, to achieve the progressive realisation of each of these rights (Sunstein, 2001). Finally in this regard, no one may be refused emergency medical treatment."

Section 27 (2), which requires the state (only the state) to take reasonable legislative and other measures in order to achieve the progressive realisation of the right of access to health care services (Pieterse, 2007). The state limited the right to health care services, as stated in section 27 (1) "the right to have access to," instead of "having a right to" (Mubangizi, 2008). According to the Limburg principles on the implementation of the International Covenant of Economic, Social and Cultural Rights Para 21 pp. 63-78 in Economic, Social and Cultural Rights: A compilation of Essential Documents International Commission of Jurists, 1977, progressive realisation does not imply that the state can defer indefinitely, efforts for the full realisation of the right. On the contrary, state parties are to "move expeditiously as possible towards the full realisation of the right and are required to make immediate steps to provide a minimum core entitlement (De Schutter , 2009).

Brand and Heyns (2005) described how and what should be done to make health care services available to all.

"respect the right of access to health care services by not unfairly or unreasonably getting in the way of the people 
accessing existing health care services, whether in public or private sector; protect the right by developing and implementing a comprehensive legal framework to stop people who get in the way of the existing access to others; promote the right by creating a legal framework so that individuals are able to realize their rights on their own; fulfill the right by creating the necessary conditions for people to access health care, by providing positive assistance, benefits and actual health care services."

The first socio-economic rights matter to reach the Constitutional Court in Soobramoney v Minister of Health, Kwazulu Natal 1997 (12) BCLR 1696 (CC). The appellant, a 41 year old, was in the final stages of chronic renal failure. He had been receiving renal dialysis through private care, but had exhausted his funds. Without dialysis, he would die sohe sought dialysis from a state renal unit, but his request was declined on account of limited resources. The unit's budget allocation from the provincial health authority did not provide sufficient dialysis machines, bed spaces, or health care personnel have to meet the demand for dialysis.

The appellant brought his claim under section 27 (3) of the Constitution, dealing with emergency treatments that argued, when read together with the right to life in terms of section 11 of the Constitution, obligated the state to provide ongoing renal dialysis. The court dismissed the claim, since the situation was not an emergency calling for immediate remedial treatment. It was an ongoing or chronic state of affairs, resulting from an incurable deterioration of the applicant's renal function (Choma, 2009). Therefore, section 27 (3), stating that "no one may be refused emergency medical treatment", did not give such a person a right to be admitted to the dialysis program at state hospital (Choma, 2009).

The Constitutional Court held that the applicant could not succeed in his claim and found that the denial of the required treatment did not breach the section 27 (1) right of everyone to have access to health care services, and the section 27 (3) right to emergency medical treatment. This decision "represents the low water-mark in relation to the application of socio-economic rights by the court." (Devenish, 2007).

This case highlights the availability of resources as the crucial consideration when determining the enforcement of a socio-economic right against the state. In this regard, the Court failed to inquire whether priorities within the provincial and national governments' health care budgets were in consonance with its constitutional obligation (Ngwena, 2000). The Constitutional Court has on a few occasions described what the "duty to take reasonable steps" means. In the case of Minister of Health \& Others v Treatment Action Campaign (TAC) 2002 (5) SA 721 (CC), the TAC took the Government to court to challenge the state's policy on mother-to-child transmission of HIV. The Court decided: children are especially vulnerable and their needs are "most urgent" because, if they do not get access to nevarapine, they will die. In cases like these, poor children depend on the state to save their lives, and the Government's policy not to provide these life-saving drugs, was therefore unreasonable and unconstitutional.

\subsection{Refugees and undocumented migrants}

The Refugees Act 130 of 1998 refers to refugees as people who have been granted asylum in South Africa in terms of the Act. A person qualifies for refugee status if that person, owing to a well-founded fear of being persecuted for reasons of race, religion, nationality, membership of a particular social group or political opinion, is outside the country of his or her nationality and is unable to, or owing to such a fear unwilling to avail him or herself to the protection of that country in terms of Section 3 (a) of the Act.. A person also qualifies for refugee status if compelled to leave his or her country of origin due to war or events which seriously disturb public order in the country or part of it. Once granted refugee status, the status is regularly reviewed and a person's refugee status ceases if the circumstances which gave rise to the recognition of refugees cease to exist and no other circumstances justify continued recognition as a refugee in terms of section $5(\mathrm{e})$.

Section 27 (1) (g) of the Act which states that: a refugee is entitled to the same basic health care and basic primary education which the inhabitants of the Republic receive from time to time. This means that all refugees, illegal immigrants, asylum seekers and undocumented migrants should enjoy the right to health care services together with South African citizens (Pieterse, 2004).

In Khosa \& Mahlaule v Minister of Social Development 2004 (6) SA 505 (CC); the Constitutional Court considered whether the law could exclude permanent residents from accessing certain forms of social security. In terms of the Social Assistance Act 59 of 1992, only South African citizens were entitled to access old age pensions, child supports grants and care dependency grants. But in terms of the Constitution, everyone has a right to social security, including social assistance where necessary (Choma, 2010).

The Constitutional Court found that it is unconstitutional to deny permanent residents access to social grants, in 
cases where they would otherwise qualify. The court made the following crucial distinction between permanents residents and temporary (including illegal) residents: "the exclusion of all non-citizens who are destitute, however, irrespective of their immigration status, fails to distinguish between those who have become part of our society and have made their homes in South Africa, and those who have not." (Brand and Heyns, 2005).

The Court did not consider whether other non-citizens other than permanent residents should be entitled to access social security (as the applicants before the Court were all permanent residents), nor did not it consider whether access to public health care services should be treated in the same way as access to social security (as the issue was not before them).

Undocumented migrants refer to people who are unlawfully in South Africa because of illegal entry, expiry of legally acquired work, study or visitors permits or because they have not yet applied for asylum seeker status (Fish, 2013). In the case of Lawyers for Human Rights v Minister of Home Affairs 2004 (4) SA 125 (CC). The Constitutional Court considered the rights of illegal immigrants who are detained at ports of entry pending their removal from the country. In its judgment, the Court rejected the state's argument that illegal foreigners have no right to claim constitutional protection. However, the Court held that it is reasonable and justifiable to limit the rights of illegal foreigners to freedom and security, thereby upholding the arrest and detention sections of the Immigration Act 13 of 2002.

\subsection{Adequate medical treatment in prison}

In South Africa, prisoners enjoy a direct and immediate entitlement to the goods and services guaranteed by the constitution (Pieterse, 2007). It is the duty of the State to provide antiretroviral treatments to prisoners. Section 35 (2) (e) of the Constitution provides that everyone who is detained, including every sentenced prisoner, has the right to the conditions of detention that are consistent with human dignity as well as the provision, at state expense, of medical treatment. In addition section 35 (2) (f) entitles a detained person to be visited by his or her chosen medical practitioner. Section 237 in turn provides that all constitutional obligations must be performed diligently and without delay. Section 21 (2) (b) (vi) enjoins the Director-General to "issue, and promote adherence to norms and standards on health matters, including health services for convicted persons and persons awaiting trial."

In Van Biljon v Minister of Correctional Services 1997 (6) BCLR 789 (C). The applicants in this case were four sentenced HIV-infected prisoners who applied for a declaratory order to medical treatment for the provision of expensive anti-retroviral(ARV) medications. The minister argued that the state was only obliged to provide the applicants with the same standard of care as was provided in state hospitals, where use of the drugs was limited and as a result the applicants would not have qualified for the drugs under the policy in place in state hospitals. The court granted the order, in deciding what is "adequate", there must be regard for "what the state can afford". Prison authorities cannot simply plead poverty, they have to make out a case that they "cannot afford a particular form of medical treatment or that the provision of such medical treatment would place an unwarranted burden on the state". If it is proved that "anything less than a particular form of medical treatment would not be adequate, the prisoner has a constitutional right to that form of medical treatment", subject to the considerations of available resources.

Interestingly, what is "adequate" medical treatment in prison may include services that are not ordinarily provided for in the public sector. This is because prison conditions may place the health of detainees at significantly higher risk to infectious diseases like tuberculosis than that of people outside the prison (Petersilia, 2001). At that time, both the state's and prisoners' medical experts recognised that ARV treatment was the "state of the art' medical treatment" for HIV infection that was generally unavailable in the public health system. Of the four applicants, only the first two were already in possession of prescription for ARV medicines.

Despite the medicines being unavailable in the public sector, the Court nevertheless directed the state "to supply first and second applicants" with ARV medications which had been prescribed for them, for as long as these medications are prescribed for them on medical grounds. But the Court refused to make a general order regarding the provision of ARV treatments to other similarly situated prisoners. Its decision was restricted to the particular facts before it, one of which was the state's failure to show why it was unable to afford treating those particular prisoners.

In N and Others v Government of Republic of South Africa (No 1) 2006 (6) SA 542 (D). The applicants were 15 prisoners incarcerated at the Westville Correctional Services who had HIVIAIDS and who qualified for antiretroviral treatments (ARV) under the Department of Health's Operational (Operational Plan). They sought orders against the respondents (various government officials) to the effect that they should be provided these medications with supportive facilities and health providers.

The orders were sought on the basis that the respondents were in breach of their constitutional obligations to ensure that the applicants and other HIVIAIDS-infected prisoners received adequate medical treatments in that they (the 
respondents) were delaying, without good cause, their fulfillment of those obligations.

The court granted the orders sought, saying section 237 meant that an otherwise reasonable but unreasonable implemented programme aimed at the fulfillment of the State's constitutional obligations would be in breach of the obligations concerned. The respondents' implementation of the laws and policies pertaining to their provision of adequate medical treatments to HIVIAIDS-infected prisoners as unreasonable in that it was inflexible and was aimed primarily at the general public rather than prisoners and was also being characterised by unjustified and unexplained delays. Furthermore, the treatments and medical care afforded the applicants and other HIVIAIDS-infected prisoners at WCC were neither adequate nor reasonable. Consequently, the respondents had fallen short of their constitutional and legislative obligations to the applicants (Matlala, 2007).

According to section 79 of the Correctional Services Act 111 of 1998 that states that any person serving any sentence in a prison, and who, based on the written evidence of the medical practitioner treating that person, is diagnosed as being in the final phase of any terminal disease or condition, may be considered for placement correctional supervision or on parole to die a consolatory and dignified death.

In DP v Minister of Correctional Services (Unreported judgment, case no: 6399/04, TPD), the applicant had committed armed robbery and was sentenced to 15 years imprisonment. He was admitted to the prison hospital at an early stage of his imprisonment with leukemia and was given an estimated life expectancy of one to two years. At the time of the application for parole on medical grounds, this life expectancy had dropped from one year to three months. The Parole Board refused the application for parole and this decision was approved by the Head of the Prison. The prisoner made an application to review the decision to refuse his release on medical grounds.

The court set aside the initial decision and ruled that the prisoner should be placed on parole subject to the following conditions: that he be monitored by the Department of Community Corrections in accordance with the statutes and regulations pertaining to Correctional Services; that he continued to be under the supervision of his doctor at the local hospital; in the event of his being discharged from the hospital, that he be placed under the care of his wife at their home; that he be under house arrest except for being allowed to undergo any medical treatment at any hospital, clinic, doctors consulting rooms or hospice. The judge commented that there is a tension between the necessity of imprisonment and the need to be compassionate towards someone suffering from a terminal illness.

The applicant's doctor noted that prison conditions were not conducive to the applicant's medical treatment. It was difficult to administer medication; he was exposed to opportunistic infections from other sick prisoners; his state of health required daily palliative care and regular hospice intervention but there are no Department of Community Services (DCS) doctors skilled in providing such care; and prison officials did not provide him with the specific food prescribed for his condition, ostensibly as a result of budget constraints.

On the 26 June 2006, the court ordered the government to:

"remove the restrictions that prevent the applicants and all other similarly situated prisoners at Westville Correctional Centre, who meet the criteria as set out in the National Department of Health's Operational Plan for Comprehensive HIVIAIDS Care, Management and Treatment for South Africa, from accessing anti-retroviral treatment at an accredited public health facility, and that (government) is ordered with immediate effect to provide anti-retroviral treatment to the applicants and all other prisoners at Westville, at an accredited public health facility."

Significantly, the judge equated the refusal to place the applicant on medical parole with an infringement of his inherent right to dignity. The judge held that the refusal further violated his rights not to be treated or punished in cruel, inhuman or degrading way- Section 12 (1) (e); to have access to health care services- Section 27 (1) (a); to be detained in conditions consistent with human dignity, including nutrition and medical treatment Section 35 (2) (e); to access to information Section 32 (1) (a) and (b); to just administrative action- Section 33 (1) and (2).

\section{Legal Frameworks that Provides the Right to Have Access to Health Care Services}

\subsection{The National Health Act}

This Act came into force in May 2005 and it is the most important piece of legislation that helped to implement the Constitutional rights on health care. Although there are other pieces of legislation that deal with health care rights, but the National Health Act is the most important statute that gives clear direction on health rights in South Africa. It aims to; protect, respect, promote and fulfill the rights of people of South Africa to progressively realize the constitutional rights to health and provide an equitable manner available to the population equitable and efficiency, establish a national system 
that will provide people with the best possible health services that available resources can afford.

\subsection{The Mental Health Care Act 17 of 2002}

This Act recognises that health is a state of physical, mental and social well-being and that mental health care services should be provided at all levels of the health system. It aims to; regulate mental health care in a way that makes the best possible mental health care, treatment and rehabilitation services available to the population, equitably, efficiently and in the best interest of the mental health care users within its limited available resources, set out rights and duties of the mental health care user, and the duties of mental health care providers, respect the human dignity and privacy of every mental health care user.

\subsection{The Sterilization Act 12 of 1998}

The Act allows the right to sterilisation and sets out the circumstances when a sterilisation can be performed. The Sterilisation Act also deals with the sterilisation of people with a severe mental disability. It explains what severe mental disability means and who needs to consent when a person has a severe mental disability, and wants or need to be sterilized. This Act defines sterilisation as a surgical operation to make a woman incapable of falling pregnant. It recognizes; that the Constitution protects the right to bodily and psychological integrity of persons which includes the right to make decision concerning reproduction and the right security in and control of their bodies, that both women and men have the right to be informed of and to have access to safe, effective, affordable and acceptable methods of fertility regulation.

\subsection{The Medical Schemes Act}

This Act came into operation on 20 November, 1998. This Act protects the interests of members of medical schemes by setting out the guidelines on the terms and conditions for membership of schemes in terms of Sections 20-28.

The Act prohibits unfair discrimination on a number of grounds and risk rating, in other words, making people pay more because they are seen as being part of a 'higher risk' group. The Act prescribes that the premiums (what people have to pay) must be based on, income and / or the number of dependents, and except on any other grounds, including sex, past or present state of health of the applicant or the applicant's dependents, or the frequency of providing relevant health services to the applicant or dependants of the applicant.

However, the Act does impose certain penalties for late joiners to medical schemes. A late joiner means an applicant or the dependent of an applicant who, at the date of the application for membership, is 40 or older and has not been a member of another medical scheme during a period of two years before applying for membership in terms of section 1 of the Act.

\subsection{The Correctional Services Act}

This Act places a duty on the Department of Correctional Services to provide all prisoners with adequate health care services. The Department must provide, within its available resources, adequate health care services, based on the principles of primary health care, in order to allow every prisoner live a healthy life in terms of section 12(1). The Act says that every prisoner has the right to adequate medical treatment, but no prisoner has a right to cosmetic medical treatment, such as the removal of tattoos or implants of breasts at State's expense.

The Act also says that every prisoner has the right to be visited and examined by a medical practitioner of his or her choice and may be treated by this practitioner as long as the Head of Prison has given permission. In this kind of case, the prisoner will have to pay for the medical treatment- Section 12 (3).

\subsection{The Children's Act}

Section 11 (3) of the Act states that a child with disability or chronic illness has the right not to be subjected to medical, social, cultural or religious practices that are detrimental to his or her health, well being or dignity. The Act also restricts virginity testing and outlaws female genital mutilation or circumcision. 


\subsection{The White Paper for the transformation of Health System in South Africa}

The Minister of Health published the White Paper on the Transformation of the Health in South Africa in Government Gazette on the 16 of April 1997. This White Paper presents the policies, objectives and principles upon which a unified health system of South Africa will be based. It aims to; unify the fragmented health services at all levels into a comprehensive and integrated National Health System (NHS), to reduce disparities and inequities in health services delivery and increase access to improved integrated services, based on primary health care principles, to give priority to maternal, children's and women's health (MCHW), and to mobilise all partners, including the private sector, Non Governmental Organisations (NGO's) and communities in support of an integrated NHS.

\section{Conclusion}

The right to access health care is constitutionally justifiable in South Africa. Section subsections 27 (2) and 26 (2) give constitutional approval and authority to this. Though the issue of adequacy or not is still being contested at every opportunity but this does not remove the fact that there should be adequate access.

\section{References}

Aliber M 2003. Chronic Poverty in South Africa: Incidence, Causes and Policies, World Development, 31(3):473-490.

Andrews A 2000. Health Care Rights, in Sandra Liebenberg and Pillay K, Socio-Economic Rights in South Africa, Juta, Cape Town, South Africa.

Bachenberg K, Bhojani A, Casey E, Choe Y, Dhami M, Dodson C, Fellerman J, Goswamy N, Hastings T, Hess K, Joswiak N, Lopez G, Meigs J, Patel A, Riley B, Sternberg E, Tillman C, Van Houten S, 2011. Show Me the Money: Achieving Economic, Social, and Cultural Rights through Government Budgets. From http://hdl.handle.net/1773/16494. (Retrieved December 25, 2013).

Brand D, Heyns C 2005. Socio-economic Rights in South Africa, 2005 Pretoria University Law Press, Pretoria, South Africa.

Campbell SM, Roland MO, Buetow SA 2000. Defining quality of care, Social Science \& Medicine, 51(11):1611-1625.

Choma HJ 2009. Constitutional enforcement of socio-economic rights: A South African case study, US China Law Review, 6(55):12-25.

Choma HJ 2010. The Protection and Enforcement of Socio-economic Rights in South Africa, 161-162.

Chopra M, Daviaud E, Pattinson R, Fonn S, Lawn JE 2009. Saving the lives of South Africa's mothers, babies, and children: can the health system deliver? The Lancet, 374(9692):835-846.

Coovadia H, Jewkes R, Barron P, Sanders D, McIntyre D 2009. The health and health system of South Africa: historical roots of current public health challenges, The Lancet, 374(9692):817-834.

De Schutter $O$ 2009. Large-scale land acquisitions and leases: A set of core principles and measures to address the human rights challenge, From vorige.nrc.nl. (Retrieved May 17, 2013).

De Vos M 2009. Using quality indicators to improve hospital care: a review of the literature

de Vos M, Graafmans W, Keesman E, Westert G, van der Voort PHJ 2007. Quality measurement at intensive care units: which indicators should we use? Journal of Critical Care, 22(4):267-274.

Devenish GE 2007. The nature, evolution and operation of socio-economic rights in the South African Constitution, THRH, 70(1):84-95.

Fish JN 2013. Rights across borders: policies, protections and practices for migrant domestic workers in south africa, Pretoria Uuniversity Law press, Pretoria, South Africa.

Graafmans W, Kooistra M, Meijboom B 2009. Quality in Health Care, International Journal of Quality Health Care, 21(2):119-129.

Greenstein R 2006. Social rights, essential services, and political mobilization in post-apartheid South Africa, Journal of Consumer Policy, 29(4):417-433.

Kahn K 2006. Dying to make a fresh start: mortality and health transition in a new South Africa, From http://su.diva-portal.org/smash Irecord.jsf?pid=diva2:145081. (Retrieved March 4, 2012).

Klasen S 1997. Poverty, Inequality and Deprivation in South Africa: An Analysis of the 1993 Saldru Survey, Social Indicators Research Series, 1:51-94.

Limburg 1977. principles on the implementation of the International Covenant of Economic, Social and Cultural Rights Para 21 pp. 63-78 in Economic, Social and Cultural Rights: A compilation of Essential Documents International Commission of Jurists.

Mabidi MB 2013. A critical discussion of the right of access to health care services and the National Health Insurance Scheme. From ul.netd.ac.za. http://ul.netd.ac.za/handle/10386/1036. (Retrieved December 15, 2013).

Mandela NR 1991. "Address on the occasion of the ANC's Bill of Rights Conference, in a Bill of Rights for a Democratic South Africa: papers and report of a conference convened by the ANC's constitutional committee, May 1991 (Centre for Development Studies, UWC).

Matlala D 2007. Duty of State to provide antiretroviral treatment, De Rebus, 40-54.

Migué JL 2002 . Funding and Production of Health Services: Outlook and Potential Solutions. From http://publications.gc.ca/site larchivee-. (Retrieved April 2, 2012).

Mubangizi JC 2007. Prospects and Challenges in the protection and enforcement of socio-economic rights: Lessons from the South 
African experience, Paper presented on VII World Congress of the International Association of Constitutional Law at Athens, 1115 June 2007.

Mubangizi JC 2008. Protecting Human Rights amidst Poverty and Inequality: The South African Post-apartheid Experience on the right of access to Housing, African Journal Legal Studies, 2(2):133-146.

Ncayiyana DJ 2008. National health insurance on the horizon for South Africa, April 2008, South African Medical Journal, 98(4):229241.

Ngwena C 2000. The Recognition of Access to Health Care as a Human Right in South Africa: Is it enough?" Health \& Human Rights, $5(1): 26-44$.

NHI. National Health Insurance in South Africa, Policy Paper. From http://www.doh.gov.za. (Retrieved November 4, 2013).

Nienaber A 2009. The involuntary isolation of patients with XDR-TB: Is the term 'health service' in section 7 of Act 61 of 2003 interpreted too broadly. From http://www.sabinet.co.za/abstracts/sapr/sapr_v24_n2_a23.html. (Retrieved July 10, 2013).

Petersilia J 2001. Prisoner reentry: Public safety and reintegration challenges, The Prison Journal, 81(3): 360-375.

Pieterse M 2007. "Enforcing the right not to be refused emergency medical treatment: towards an appropriate relief" Stellenbosch Law Review, 1:1-12.

Pieterse M 2004. Possibilities and Pitfalls in the Domestic Enforcement of Social Rights: Contemplating the South African Experience, Human Rights Quarterly, 26(4):882-905.

Pieterse M 2007. Indirect horizontal application of the right to have access to health care services, South African Journal on Human Rights, 1:163-174.

Pieterse M 2007. Health Care Rights, Resources and Rationing, South African Law Journal, 1:522-523.

Price M 1986. 'Health care as an instrument of apartheid policy in South Africa, Health Policy and Planning Journal, 1(2):158-170.

Price M 1998. The consequences of health service privatisation for equality and equity in health care in South Africa, Social Science \& Medicine, 27(7):703-716.

Roston 2005. High Water Rising in the Cape, Business Day (South Africa), December 13, 2005, at 11.

Sarkin J 1998. The development of a Human Rights Culture in South Africa, Human Rights Quaterly, 20:628-645.

Sunstein C 2001. Social and economic rights? Lessons from South Africa, University of Chicago, Public Law Working Paper, $12(124): 1-$ 14.

van Rensburg HCJ, Benatar SR 1993. The legacy of apartheid in health and health care, South African Journal of Sociology, 24(4): 99111. 
